\title{
MOTIVATIONAL FACTORS AND AMENITIES FULFILLMENT OF SOUTHERN RAILWAY EMPLOYEES - A EMPIRICAL STUDY WITH REFERENCE TO TIRUCHIRAPPALLI DIVISION
}

\author{
U. Rohith \\ M.Phil Research Scholar, Department of Commerce, VISTAS, Chennai, India \\ Dr. P. Jagadeesan \\ Professor and Head, Department of Commerce, VISTAS, Chennai, India
}

\begin{abstract}
This empirical study was primarily examined to understand the motivational factors and amenities fulfillment of employees working in southern railways in Tiruchirappalli division of Tamil Nadu. The researcher adopted survey method to collect response from railway employees through structured questionnaire by applying convenient sampling technique. The statistical tools such percentage analysis and mean based ranking has been applied to draw meaningful findings for the research objectives. The result indicates that salary is consider as the highest motivating factors, followed by promotion activities and recognition in their order of preference.
\end{abstract}

Keywords: Motivation, Amenities, Railway Employees, Promotion and Recognition.

Cite this Article: U. Rohith and Dr. P. Jagadeesan, Motivational Factors and Amenities Fulfillment of Southern Railway Employees - A Empirical Study with Reference to Tiruchirappalli Division, Journal of Management (JOM), 6 (3), 2019, pp. 179-185. http://www.iaeme.com/JOM/issues.asp?JType=JOM\&VType=6\&IType=3

\section{INTRODUCTION}

The term stress originates from physical science where it refers to the force placed upon an object to cause straining, bending, or breaking. In the human context and in psychology, however, stress is often used to describe the body's responses to demands placed upon it, whether these demands are favorable or unfavorable. Anything that causes stress is called a stressor. In popular terms, stress is mainly defined as time pressure. We feel stressed when we do not have the time to perform the tasks that we want to perform within a given period. The perception of time pressure usually triggers a set of physiological reactions that indicate that we are stressed (Centre for Studies on Human Stress). Stress results from the tension between an individual's reaction to difficulties or challenges and his or her ability to handle and resolve 
the stressful situation. How people cope with stress depends on the resources that are available to them and whether they have the skills to utilize these resources. The term stressor relates to a challenging occurrence that may produce stress.

Stress is the way human beings react both physically and mentally to changes, events, and Situations in their lives. People experience stress in different ways and for different reasons. The reaction is based on your perception of an event or situation. If you view a situation negatively, you will likely feel distressed overwhelmed, oppressed, or out of control. Distress Is the more familiar form of stress. The other form, estruses, results from a "positive" view of an event or situation, which is why it is also called "good stress. "Eustress helps you rise to a challenge and can be an antidote to boredom because it engages focused energy. That energy can easily turn to distress, however, if something causes you to view the situation as unmanageable or out of control. Many people regard public speaking or airplane flights as very stressful causing physical reactions such as an increased heart rate and a loss of appetite while others look forward to the event. It's often a question of perception: A positive stressor for one person can be a negative stressor for another.

\section{REVIEW OF LITERATURE}

Nadeem Malik (2011) examined the impact of occupational stress produced upon bank employees. A sample of 200 employees from private and public banks in Quetta City showed that occupational stress was found higher among private bank employees compared to public bank employees. The study had indicated that in both sectors role overload, role authority, role conflict and lack of senior level support were found to be the major stressors among different occupational stress variables. The study also indicated that the private employees have high workload compared to public bank employees. The study concluded that the bank employees cannot afford the time to relax and "wind down" when they were faced with work variety, discrimination, favoritism, delegation and conflicting tasks.

Swaminathan and Rajkumar (2013) examined the stressors in a sample of 250 working professionals from self-owned establishments, corporate, banks and educational institutions in Chennai. They identified some stressors such as degree of work freedom, manipulation, office politics and environment of trust or mistrust. Their study found that office politics was a major stress among the employees. It was understood that high stress level were found among the respondents having own business and the respondents over 20 years' experience. With respect to the type of job, the field job entailed a lot of stress and heavy pressure due to meeting targets, frequent travel, meeting all types of clients, working in irregular hours, daily reporting and strict control by top management. The study suggested that good relationship with colleagues reduces chance of manipulation and office politics and promotes understanding.

Dhanalakshmi (2008) intended to measure the level of stress of the Transport Corporation employees and study the factors that could predict stress. The study was conducted on the list of conductors and drivers from the administrative office in the two branches of Tamil Nadu State Transport Corporation in Coimbatore. It was found that the employees experienced moderate level of stress and the factors identified were health conditions, working conditions, monetary benefits, timing of work and grievance redressal. The stress was influenced by the pressure inherent in the job such as handling the public commuters and the condition of the bus. It had been felt that the management of the Corporation in order to stand the competition has gradually started making the employees accountable for each commuting trip they play. The pressures on the employees' made them feel insecure. The study suggested that the employees may become more passenger-friendly in order to facilitate the smooth conduct of the bus travel. 


\section{NEED OF THE STUDY}

Stress is a normal part of human life in the modern world. The effect of stress is a deviation from the existing physical and psychological damage of human life. Stress is unavoidable and can occur in all facets of life. Stress that is prolonged and managed poorly can result in negative physical, mental, and cognitive outcomes for humans. Other negative outcomes include anxiety, depression, weakened immune system, heart disease, obesity, and poor memory. The aim of this paper is to identify the level of stress among Rail road employees (railway employees) in Tiruchirapalli division. The work of railroad employees is considered as extremely stressful and this paper deals with factors that lead to stress and fatigue and thus to high probability of accident. The aim of this paper is to bring an extensive review of knowledge on stress, fatigue and working conditions regarding to job out- comes of railway employees.

\section{SCOPE OF THE STUDY}

The study is based mainly on the railroad employees working in railway department. The study is carried out to define how the railway department should be work in terms of managing work related stress. It identifies the top most reason for employees affected by stress in railway department.

\section{OBJECTIVES OF STUDY}

- To know the study is identify the motivational factors among the employees working in railway department.

- To explore the amenities fulfilment of railway employees in the southern railway

\section{LIMITATION OF STUDY}

The research study is limited to a small sample size. Some of information given by the respondents may not be reliable. I was not able to collect the information from all the employees because of busy schedule of employees. The period of the study is limited to 3 months of duration. While observing to the sample respondents and the information which was collected are correct, so there is no chance of sampling error. The study is confined only to employees of railway department in Tiruchirapalli division. Therefore the results and conclusion of study is may not be applicable to other division

\section{RESEARCH METHODOLOGY}

Research methodology is a way to solve a systematic research problem. It explains the various studying the research.

\subsection{Research Design}

A research design is an arrangement of conditions for collection and analysis of data in a manner that aims to combine relevance to the research purpose with economy in procedure.

It provides a scientific framework for conducting some investigation. The research should specify the approach with respect of to the purposed study. In this study descriptive research portrays accurately the characteristics of a particular individual, situation or a group. The descriptive research includes surveys and fact finding enquires of different kinds the major purpose of descriptive research is description of the state of affairs as it exists at present the descriptive study is under taken in order to ascertain and to describe the characteristics of the variables. 


\subsection{Sample Size}

Hence for the study a sample 130 questionnaires has been circulated among the railway employees in Tiruchirapalli division. I received sample sizes of 124 from the railway employees working in the Tiruchirapalli division and taken on base of convenient sampling.

\subsection{Data collection:}

Both primary and secondary data is used in the project. Primary data are the information collected directly from the railway employees working in the Tiruchirapalli division using the structured questionnaire. And secondary data is the information's collected from journals, articles, reports, and internet.

\section{ANALYSIS AND INTERPRETATION}

Table 1 Gender of the Respondents

\begin{tabular}{|c|c|c|}
\hline Gender & Frequency & Percentage\% \\
\hline MALE & 111 & 89.5 \\
\hline FEMALE & 13 & 10.5 \\
\hline TOTAL & $\mathbf{1 2 4}$ & $\mathbf{1 0 0 . 0}$ \\
\hline
\end{tabular}

The table 1 clearly shows that out of 124 respondents, in which $89.5 \%$ respondents are male and $10.5 \%$ respondents are female.

Table 2 Age of the Respondents

\begin{tabular}{|c|c|c|}
\hline Age & Frequency & Percentage \% \\
\hline 21-30 years & 44 & 35.5 \\
\hline 31-40 years & 37 & 30 \\
\hline 41-50 years & 18 & 14.5 \\
\hline 51 and above & 25 & 20 \\
\hline Total & 124 & 100 \\
\hline
\end{tabular}

Table 2 clearly shows that $35.5 \%$ of the respondents are coming under the category of 21 30 years, $30 \%$ of respondents are in the category of $31-40$ years, $14.5 \%$ of the respondents are in the category of 41-50 years and $20 \%$ of respondent are in the category of above 51 years.

Table 3 Educational Qualification of the Respondents

\begin{tabular}{|c|c|c|}
\hline Educational Qualification & FREQUENCY & Percentage \% \\
\hline SSLC & 51 & 41.1 \\
\hline Hs/Diploma & 29 & 23.4 \\
\hline Under Graduate & 18 & 14.5 \\
\hline Post Graduate & 13 & 10.5 \\
\hline Others & 13 & 10.5 \\
\hline Total & 124 & 100.0 \\
\hline
\end{tabular}

The table 3 indicates that out of 124 respondents, $41.1 \%$ respondents have SSLC, $23.4 \%$ respondents are Hs/Diploma holders, $14.5 \%$ respondents are under graduate, $10.5 \%$ respondents are post graduate, and $10.5 \%$ respondents are below SSLC. 
Motivational Factors and Amenities Fulfillment of Southern Railway Employees - A Empirical

Study with Reference to Tiruchirappalli Division

Table 4 Convenient Shift of the Respondents

\begin{tabular}{|c|c|c|}
\hline $\begin{array}{c}\text { CONVENIENT } \\
\text { SHIFT }\end{array}$ & FREQUENCY & PERCENTAGE \% \\
\hline DAY SHIFT & 106 & 85.5 \\
\hline NIGHT SHIFT & 18 & 14.5 \\
\hline TOTAL & 124 & 100.0 \\
\hline
\end{tabular}

Table 4 explains that of $85.5 \%$ respondents are interested on day shifts, $14.5 \%$ respondents are interested night shifts.

Table 5 Income level of the Respondents

\begin{tabular}{|c|c|c|}
\hline INCOME LEVEL & FREQUENCY & PERCENTAGE \% \\
\hline Less Than 10k & 8 & 6.5 \\
\hline 10k To 25k & 100 & 80.6 \\
\hline 25k To 50k & 16 & 12.9 \\
\hline TOTAL & 124 & 100.0 \\
\hline
\end{tabular}

Table 5 shows that of 124 respondents, $6.5 \%$ responders income level is less than 10,000 , $80.6 \%$ responder are income level is 10,000 to 20,000 and $12.9 \%$ responder income level is 25,000 to 50,000 .

Table 6 Experience of the Respondents

\begin{tabular}{|c|c|c|}
\hline YEARS OF EXPERIENCE & FREQUENCY & PERCENTAGE \% \\
\hline 1 To 5 Years & 42 & 33.9 \\
\hline 6 To 15 Years & 35 & 28.2 \\
\hline 16 To 25 Years & 28 & 22.6 \\
\hline 26 To 30 Years & 10 & 8.1 \\
\hline More Than 30 Years & 9 & 7.3 \\
\hline TOTAL & 124 & 100.0 \\
\hline
\end{tabular}

Table 6 indicates that out of 124 respondents, 33.9\% respondents are 1 to 5 years' experience person, $28.2 \%$ respondents are 6 to 15 years' experience person, $22.6 \%$ respondents are 16 to 25 years experienced person, $8.1 \%$ respondents are 26 to 30 years experienced person and $7.3 \%$ respondents person are more than 30 years' experience.

Table 7 Mode of Transport of the Respondents

\begin{tabular}{|c|c|c|}
\hline MODE OF TRANSPORT & FREQUENCY & PERCENTAGE \% \\
\hline Car & 2 & 1.6 \\
\hline Bus & 26 & 21.0 \\
\hline Train & 58 & 46.8 \\
\hline Bicycle & 27 & 21.8 \\
\hline By Walking & 11 & 8.9 \\
\hline TOTAL & 124 & 100.0 \\
\hline
\end{tabular}

Table 7 shows that $1.6 \%$ respondents were traveling through car from home to work place , $21 \%$ respondents were traveling through bus from home to work place, $46.8 \%$ respondents were traveling through train from home to work places, $21.8 \%$ respondents were traveling through bicycle from home to work place, $8.9 \%$ respondents who go work place to by walk. 
Table: 8 MEAN BASED RANKING

\begin{tabular}{|c|l|c|c|c|}
\hline S.NO & \multicolumn{1}{|c|}{ Motivational Factors } & Mean & $\begin{array}{c}\text { Std. } \\
\text { Deviation }\end{array}$ & RANK \\
\hline 1 & Salary Increase & 3.24 & 1.500 & 1 \\
\hline 2 & Promotion & 3.02 & 1.316 & 2 \\
\hline 3 & Leave & 2.98 & 1.411 & 3 \\
\hline 4 & Motivational Talks & 2.72 & 1.316 & 5 \\
\hline 5 & Recognition & 2.90 & 1.506 & 4 \\
\hline
\end{tabular}

Table 8 clearly shows that increase in salary is consider as the highest motivating factors (3.24), promotion activities motivated to employees (3.02) level, leave is the (2.98) level motivated to respondents, and also motivational talks, recognition is low level to motivated to respondents (2.90) and (2.72).

Table 9 Amenities

\begin{tabular}{|c|l|c|c|c|}
\hline S.NO & \multicolumn{1}{|c|}{$\begin{array}{c}\text { AMENITIES PROVIDE BY RAILWAY } \\
\text { DEPARTMENT }\end{array}$} & $\begin{array}{c}\text { Std. } \\
\text { Deviation }\end{array}$ & RANK \\
\hline 1 & Railway hospital \&reimbursement of medical expenses & 3.24 & 1.500 & 1 \\
\hline 2 & Life time free pass & 3.02 & 1.316 & 2 \\
\hline 3 & Railway schools, Colleges \& Students Scholarship & 2.98 & 1.411 & 3 \\
\hline 4 & Quarters(house)\&hostel for women employees & 2.72 & 1.316 & 5 \\
\hline 5 & Free family tour \& holiday homes & 2.90 & 1.506 & 4 \\
\hline
\end{tabular}

Table 9 shows that most of the respondents highly satisfied railway hospital \& reimbursement of medical expenses (3.24), life time free pass are satisfied in (3.02), railway schools, colleges and students scholarship are satisfied level is (2.98), free family tour and holiday homes satisfied to (2.90), and quarters(house)and hostel for women employees are satisfied in (2.72).

\section{SUGGESTIONS AND CONCLUSION}

Increased workload, in combination with the sense that the work role contradicts the family one, lead to development of occupational stress. Levels of intervention are recommended in order to development of occupational stress. Levels of intervention are organization itself. The targets include the identification and evaluation of the existing stressors, as well as corrective measures. A part of their occupational stress management is potential factors that contribute to the development of occupational stress, we recommend the following:

Evaluation of occupational stress risk factors and management of these risks, taking preventive measures for the employees. Reduction of work overload with rational management of human resources regarding rail road employee establishes a balance between work demands and capabilities of the rail road employees. The focus on persons includes an individual guided training, by railway department for occupational stress management support groups.

Therefore, it is necessary that executives specialized in such fields will be recruited in railway departments. Consequently, mechanisms for prevention and management of occupational stress should act coordination and focus early on minimizing the stressors, on one hand, and on enhancing psychophysical stability of rail road employees, on the other. It is essential to reorganize work environment (in its broad sense) and remove as many as possible stressors, along with training of staff in ways with which they can manage stress and achieve better adjustment. 
All these should be coordinated by employers and take place within the workplace. This interest from employer part should be sincere and visible, in order to promote employees 'health and safety. The review demonstrated that a great deal is known about the sources of stress at work, about how to measure it and about the impact on a range of outcome indicators. What was found to be lacking was a translation of these results into practice, and research that assesses the impact of interventions that attempt to moderate, minimize or eliminate some of these stressors. Therefore, it is important to understand how work-associated stress affects rail road employees, and what factors in their working environment cause the greatest burden. It is also of great importance to gain more knowledge about railroad employee' working conditions, Occupational stress and job satisfaction - knowledge that might be used to decrease their occupational stress and increase their job satisfaction. In an effort to contribute to the development of such knowledge. The working conditions, occupational stress, health condition cause stress among rail road employees. However, it is not only organizational factors and tasks that cause occupational stress. The interaction between organizational factors and tasks that cause occupational stress. The interaction between organizational factors and the characteristics of individual workers also plays a significant role. Because of different working conditions, education, social status of the railroad employees in different culture, it can be assumed that occupational stress differs between cultures and cities, and the findings of such studies must be interpreted from the perspective of job surroundings in which they are conducted.

\section{REFERENCES}

[1] Ramezan Jahanian and Seyyed Mohammad Tabatabaei, November 2012 Stress Management in the Workplace International Journal of Academic Research in Economics and Management Sciences, Vol. 1, No. 6.

[2] Thomas G. Plante and Laura Coscarelli 2001 Does Exercising with Another Enhance the Stress-Reducing Benefits of Exercise? International Journal of Stress Management, Vol. 8, No. 3.

[3] Geeta Kumari and K. M. Pandey October 2011 Studies on Stress Management: A Case Study of Avatar Steel Industries, Chennai, India International Journal of Innovation Management and Technology, Vol. 2, No. 5.

[4] T. O. Oladinrin, O. Adeniyi, \& M.O. Udi 01 January 2014 Analysis of Stress Management among Professionals in the Nigerian Construction Industry International Journal of Multidisciplinary and Current Research Vol.2 issue 2.

[5] Dorota zołnierczyk-zreda 2002 the effects of worksite stress management intervention on changes in coping styles international journal of occupational safety and ergonomics (JOSE ), vol. 8, no. 4, 465-482.

[6] Gro Ladegard February 2011, Stress management through workplace coaching: The impact of learning experiences International Journal of Evidence Based Coaching and Mentoring Vol. 9, No. 1, Page 29.

[7] Rajendran and Jayashree 2005, stress management with special reference to public sector bank employees in Chennai, international journal of enterprise and innovation management studies (IJEIMS) vol. 1 no. 3 pp 44-58 